\title{
Economic Development and Type of Political Regime
}

\author{
Bhavya Visal
}

\begin{abstract}
Over the years, conflicting conclusions demonstrating the link between political regime and economic development have been formed by different schools of thought:

1. An authoritarian government facilities economic development.

2. An authoritarian government impedes economic development (and hence, democracy fosters economic development).

3. There is no direct relationship between the type of political regime and economic development.

In the following paper, I will evaluate all three perspectives through an objective economic lens supported by reason and evidence.
\end{abstract}

Index Terms - Economic Development, Political Regime.

\section{. I. AUTHORITARIAN GOVERNMENT: A FACILITATOR FOR ECONOMIC DEVELOPMENT}

At the heart of this perspective is the claim that economic growth is inhibited by democracy [1][2][3][4]. Proponents of this theory believe that a trade-off must be made between political democracy and economic development for a developing economy; these two policy objectives are mutually exclusive. Bhagwati [5] argues that underdeveloped countries face a "cruel choice between rapid expansion and democratic processes". It is also believed that an authoritarian government is more equipped to lead a developing country to economic development for a variety of reasons. Dick [6] went further, arguing that economic growth can only take place in the form of central planning or authoritarianism for an undeveloped country.

As a result of policy predictability and political stability, authoritarian governments foster social and hence economic stability. This is crucial in creating the right environment conducive to economic growth and development by encouraging long-term investments. Protection from outside interference can further allow an economy to grow and eventually achieve a strong competitive advantage.

In addition, with a single-minded focus on long-run economic development, authoritarian governments are more likely to enact policies oriented towards national development, unlike in democratic governments where electoral politics can distort the economy due to short-run expediency and populism. Furthermore, authoritarian regimes are more likely to achieve egalitarian development, by protecting the interests of the lower sections of society [7].

Bhavya Visal, Inventure Academy, Banagalore
An authoritarian government also has the ability to make decisions quickly and efficiently, unlike the inefficiencies of policy-making in a democracy. Not only are authoritarian regimes more able to govern, but they are also in a strategic position to effectively implement critical policies to foster rapid economic growth. Examples of such policies include the ability to apply controls on labour markets, high efficiency in the allocation of resources, the capacity to use consensus by force to overcome traditional patterns, and the facilitation of economic growth through its effects on consumption, saving and the accumulation of capital [8].

Supporters of this point of view, according to Solow growth model (1994), strongly believe that high savings and investment are essential for capital accumulation - the main driver of sustained economic development. To achieve greater economic growth, an increase in productive potential is essential through, for example, an increase in the number of factories and productive technologies. This accumulation of a surplus for investment requires sacrifices - current consumption must be reduced while simultaneously increasing savings [8]. Proponents believe that only authoritarian regimes have the capability to bolster economic growth through capital formation and that no democratic government can adhere to the necessary restraint in consumption to escalate the growth rate of a developing economy [9]. This is because democracy encourages demand for current consumption, thereby reducing investment and growth.

Proponents contend that as a universalistic actor, an authoritarian government is distanced from societal pressures and is able to restrict the pursuit of self-interest by stakeholders through command. This empowers the regime to implement appropriate policies to drive economic development, taking into account the maximum benefit of the overall population [10].

Lee Kuan Yew [11]once said, "what most countries needed for development was the discipline, not democracy", aptly summarising the stance of proponents of this point of view. For example, China experienced unprecedented growth, known as the "Asian miracle" under the Communist Party of China. Its poverty rate fell from 61.1 per cent in 1980 to 6 per cent in 2011 and its average income of $\$ 970$ skyrocketed to USD $\$ 11850$ in the same period. This rapid economic development is attributed to the authoritarian regime.

\section{DEMOCRACY: A DRIVER OF ECONOMIC DEVELOPMENT}

Advocates of this perspective challenge the effects of an authoritarian regime on the economic development of a 
country by questioning assumptions such as the propensity of the well off to save in a manner that is beneficial to the nation [12], the prevalence of distortions of economies in democracies [12] and the degree of corruption in the governments of under-developed and developing countries [13]. They strongly disagree with the presupposition that development needs to be commanded by a central authority, since that restricts citizen rights and freedoms [14].

Supporters of this model point out several flaws in the arguments of those who believe that an authoritarian government can achieve greater economic development than a democratic government. Firstly, they believe that capital-intensive growth promoted by authoritarian regimes is unbalanced and detrimental to society in the long-run [15]. Democratic governments, however, experience consumption-based growth, allowing citizens to have a wider choice and higher living standards. Underdeveloped countries often have a tendency towards corruption, waste and misuse of power that may be directed towards furthering personal gain rather than in the wider interests of society. This may be amplified under an authoritarian regime, without the checks and balances of a democratic government. According to North and Weingast [16] "For economic growth to occur the sovereign or government must not merely establish the relevant set of rights, but make a credible commitment to them."

Several economists support the belief that political democracy results in a reduction of inequalities. This is because the electoral mechanism and egalitarian political structure allows several points of view across socio-economic groups to be voiced in the political spectrum. Policies regarding the allocation of resources and benefits

can be openly debated [17][18]. For example, the high economic development of the United Kingdom and the United States may be attributed to their democratic system.

Furthermore, the provision and exercise of political rights as well as civil freedoms through democratic processes may generate societal conditions favourable to economic development [19]. Many economists [20][21][22][23][24] contend that a democratic form of government is best suited to foster sustained and equitable economic development in developing and underdeveloped countries. This is because citizens equipped with basic civil liberties and freedoms will be motivated to work, save and invest [25]. Moreover, democratic governments promote political and economic pluralism. Goodell and Powelson [23] submit that democratic mechanisms foster competition and entrepreneurial risk, creating an atmosphere conducive to economic development.

\section{TYPE OF POLITICAL REGIME AND ECONOMIC DEVELOPMENT: IS THERE A LINK?}

An alternative belief is that there is no relationship between the type of political regime and economic development [26]. It is possible that the differences in political structure have no bearing on the economic development of a country. Rather, the varying nature of economic development in countries may depend on other factors such as the level and type of state intervention in the economy, the geographical location, natural endowments, the nature of industrialization achieved (labour-intensive or capital-intensive), and the cultural and societal environment [27].

\section{EMPIRICAL EVIDENCE}

Although all three arguments are theoretically sound, the results from empirical studies are inconclusive. For example, in a study by Przeworski and Limongi[28], twenty-one findings from studies were examined wherein eight were in favour of democracy, eight were in favour of authoritarianism, and five discovered no difference. Similarly, in another research paper by Sirowy and Inkeles [8] , from thirteen studies, three findings suggest "unqualified, negative effects of democracy on economic growth rates", six studies indicate that there is no relationship between the democratic character of regimes and the pace of economic growth, while four studies showsome form of a qualified relationship. Evidence suggests that the effects of the types of political structure - democratic or authoritarian regime - on economic development vary based on circumstances in the country, sample size, time period of assessment, as well as the methodology of thestudy in terms of its "measurement, coverage, design and method of analysis" [8].

\begin{tabular}{|c|c|c|c|}
\hline Auther & Sample & Time frame & Finding \\
\hline Przeworski (1966) & 57 countries & $1949-1963$ & $\begin{array}{l}\text { dictatorships at } \\
\text { medium development } \\
\text { level grew fastest }\end{array}$ \\
\hline $\begin{array}{l}\text { Adelman and } \\
\text { Morris (1967) }\end{array}$ & $\begin{array}{l}74 \text { underdeveloped } \\
\text { countries (including } \\
\text { communist bloc) }\end{array}$ & 1950-1964 & $\begin{array}{l}\text { authoritarianism helped } \\
\text { less and medium } \\
\text { developed countries }\end{array}$ \\
\hline Dick (1974) & $\begin{array}{l}59 \text { underdeveloped } \\
\text { countries }\end{array}$ & 1959-1968 & $\begin{array}{l}\text { democracies develop } \\
\text { slightly faster }\end{array}$ \\
\hline $\begin{array}{l}\text { Huntington and } \\
\text { Dorninguez (1975) }\end{array}$ & 35 poor nations & the $1950 \mathrm{~s}$ & authoritarian grew faster \\
\hline Marsh (1979) & 98 countries & $1955-1970$ & authoritarian grew faster \\
\hline Weede (1983) & 124 countries & $1960-1974$ & authoritarian grew faster \\
\hline $\begin{array}{l}\text { Kormendi and } \\
\text { Meguire (1985) }\end{array}$ & 47 countries & 1950-1977 & democracies grew faster \\
\hline Kohli (1986) & $\begin{array}{l}10 \text { underdeveloped } \\
\text { countries }\end{array}$ & 1960-1982 & $\begin{array}{l}\text { no difference in 1960s; } \\
\text { authoritarian slightly } \\
\text { better in } 1970 \mathrm{~s}\end{array}$ \\
\hline Landau (1986) & 65 countries & $1960-1980$ & authoritarian grew faster \\
\hline $\begin{array}{l}\text { Sloan and } \\
\text { Tedin (1987) }\end{array}$ & $\begin{array}{l}20 \text { Latin } \\
\text { American countries }\end{array}$ & $1960-1979$ & $\begin{array}{l}\text { bureaucratic-authoritarian } \\
\text { regimes do better than } \\
\text { democracy; traditional } \\
\text { dictatorships do worse }\end{array}$ \\
\hline Marsh (1988) & 47 countries & $1965-1984$ & $\begin{array}{l}\text { no difference between } \\
\text { regimes }\end{array}$ \\
\hline Pourgerami (1988) & 92 countries & $1965-1984$ & democracies grew faster \\
\hline Scully $(1988,1992)$ & 115 countries & $1960-1980$ & democracies grew faster \\
\hline Barro (1989) & 72 countries & $1960-1985$ & democracies grew faster \\
\hline $\begin{array}{l}\text { Grier and } \\
\quad \text { Tullock (1989) }\end{array}$ & 59 countries & $1961-1980$ & $\begin{array}{l}\text { democracy better in Africa } \\
\text { and Latin America; } \\
\text { no regime difference } \\
\text { in Asia }\end{array}$ \\
\hline Remmer (1990) & $\begin{array}{l}11 \text { Latin American } \\
\text { countries }\end{array}$ & $\begin{array}{l}1982-1988 \\
1982 \text { and } 1988\end{array}$ & $\begin{array}{l}\text { democracy faster, but resul } \\
\text { statistically insignificant }\end{array}$ \\
\hline Pourgerami (1991) & $\begin{array}{l}106 \text { less developed } \\
\text { countries }\end{array}$ & 1986 & democracies grow faster \\
\hline Helliwell (1992) & 90 countries & $1960-1985$ & $\begin{array}{l}\text { democracy has a negative, } \\
\text { but statistically } \\
\text { insignificant, effect } \\
\text { on growth }\end{array}$ \\
\hline
\end{tabular}

Source: "Political Regimes and Economic Growth" Adam Przeworski and Fernando Limongi (1993) 


\section{CONCLUSION}

In conclusion, the impact of political regimes on economic development for developing countries is not concrete and depends on specific circumstances. Upon analysing both theoretical reasoning and empirical data, this question stilldoes not have a definitive answer and is clearly a critical area for further research.

\section{REFERENCES}

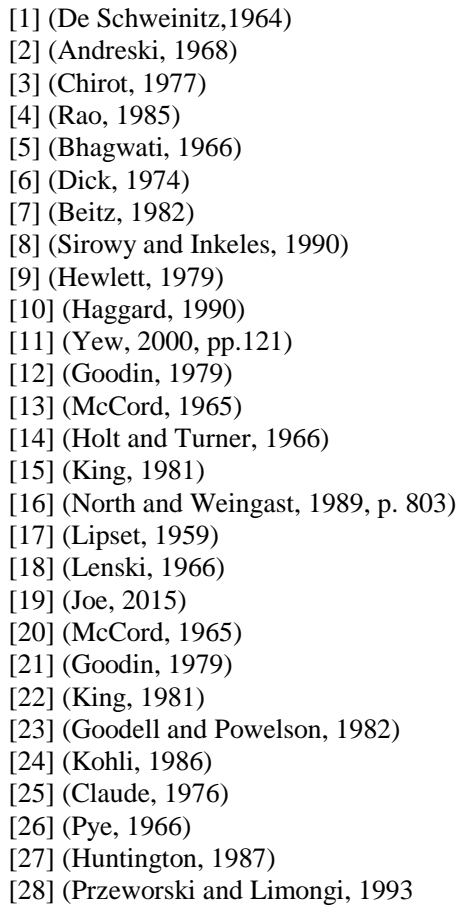

